\title{
ANÁLISE PSICOSSOCIAL DO PROCESSO SAÚDE-DOENÇA
}

Bader Burihan Sawaia*

SAWALA, B. B. Análise peicossocial do processo saúde-doença. Rev.Eec.Enf.U8P, v.28, n.1,p. 105-10, abril, 1994.

Trata-se da reflexćo sobre o paradigma transdisciplinar do processo scúde-doença, apontando a mediaçāo simbólica entre as reaçōes do organismo biológico $e$ os fatores sócio-ambientais, inclusive os patogênicos. A mediaçào simbólica trabalhada na interface com a teoria das Representaföes Sociais permite o conhecimento dos referentes das açöes individuais e coletivas do processo saúde-doença.

UNITERMOS: Representaçāo social, mediaçāo simbólica, emoçāo.

A preocupação com uma interpretação mais ampla, nâo exclusivamente fisico-biológica do processo de saúde-doença é antiga na história das ciências biológicas.

Hipócrates o criador da medicina moderna que negou a concepção de doença causada por demônio ou forças sobrenaturais, já apontava em seu livro, Ares. Aqua e Alimento, enfatizando ser a base da arte médica a compreensão da interação entre corpo, mente e ambiente. Ele considerava que os fatores culturais - como modos de vida - e os fatores psicológicos ou "componentes da natureza humana" - como humores e paixōes - somavam. se aos fatores ambientais na influência sobre o bem-estar dos indivíduos. No entanto, a história das ciências médicas nāo foi sempre linear, nem constante, mas conflituosa e antagônica e os aspectos da medicina hipocrática foram negligenciados com o predomínio da ciência cartesiana.

- Felizmente, nas últimas décadas, a relação entre fatores sócio-ambientais e organismo biológico vem sendo bastante pesquisado.

Hoje, nảo há mais necessidade de se afirmar a importância dos processos peicossociais na promoçāo da saúde. Quanto a isto, há unanimidade ou, pelo menos, ninguém discorda que a pobreza, condiçōes de trabalho, moradia, alimentação, costumes e práticas de saúde, etc. sâo fatores intervenientes no estado de bem-estar.

Doutora em Psicologia Social pela PUC-SP, Profeasor Doutor do Departamento de Orientaço Profisaional da Escola de Enfermagem da USP, Docente dos Programas de Pb́s-Greduagho em Paicologia Social - PUCSP e da Escola de Enlormagem da USP. 
O conflito reside na explicação da relação entre esses processos e os distúrbios biológicos e mentais. Quais são esses processos, qual a relação entre eles e como se dá esta relação, sāo questōes que geram acirrados deba tes e, muitas vezes, explicaçōes reducionistas e deterministas.

Muitos apontam que a dificuldade se encontra na metodologia utilizada nos estudos que objetivam superar o paradigma biologista, e não conseguem desenvolver estratégias de mensuração rigorosa dos processos psicossocia is. Mas o problema é mais abrangente, não basta ampliar o enfoque biológico no sentido de abranger o psicossocial. Ele está no paradigma de saúde que orienta a concepção desses processos, reduzindo-os à variáveis que afetam o processo saúde-doença em termos de estímulo-resposta (relaçóes causais). Este paradigma objetiva-se em metodologia de pesquisa que busca compreender a relação entre os processos sociopsicoculturais e o processo saúde-doença, unicamente através de descoberta de leis universais e invariantes, a partir da mensuraçāo dos processos envolvidos, conhecidos como fenômeno "hard", natural, que independem da forma como são vividos pelos homens.

Muitas pesquisas sobre o papel dos fatores psicossociais nas diversas etiologias baseiam-se na concepção estática de saúde como estado de completo bem-estar físico e mental, de equilíbrio e de estabilidade, interrompido pela doença causada por agente externo ao organismo onde são enquadrados, indiferenciadamente, tanto os agentes bacteriológicos e microorgânicos quanto os "agentes" psicossociais, como se tivessem efeitos patogênicos a nálogos.

Partimos do pressuposto de que a doença nāo é adquirida, exclusivamente, através da exposiçāo a fatores exógenos. Mesmo as doenças infecciosas não ocorrem unicamente por exposiçāo a as agentes patológicos de enfermidade. É preciso considerar que a relaçăo entre o processo saúde/doença e fatores sócio-ambientais não é imediata, mas mediata. A reaçảo dos sujeitos aos fatores externos (quer sejam microorgânicos, quer sejam sócio-econômicosambientais), não é mera resposta espontânea do organismo (nāo é açāo reflexa). Ela é contingencial, mediada pelo uso de signos que modelam a situaçāo estimuladora. O homem é um animal simbólico que reage frente aos significados que ele próprio constrói historicamente, e nảo às coisas em si. Estes símbolos mudam o ambiente, a natureza, a sociedade e inscrevem-se no biológico.

"A doença é uma construção social"(CONCONE, 1980). Mesmo as doenças fisicas mais diretamente ligadas às causas orgânicas "podem ser abordadas a partir dessa perspectiva, uma vez que também envolvem por um lado, uma série de representações coletivas a respeito do que é estar doente ou sentir-se doente e refletem por outro lado, a natureza sócio-econômica de uma sociedade em determinado momento da sua história" (MONTEIRO, 1985).

'A saúde ou a cura das doenças ou a busca do corpo saudável não é preocupaçāo exclusiva de médicos e paramédicos; sempre teve lugar no imaginário popular. Todos temos explicações e usamos recursos para combater as doenças, o que variam são os fundamentos das crenças e das açōes (mágico-religioso, científico...) referentes à elas. Por exemplo, muitos programas de educação e prevenção de diarréia infantil, apesar da fartura de verbas, 
da competência técnica e das boas intençōes, têm fracassado por desconsiderar a linguagem, os costumes e os valores ligados à saúde e à nutrição infantil da população envolvida.

O campo social, onde se inserem as pessoas, orienta a representação que delimita o campo das comunicaçōes, dos valores e das crenças, que regem as condutas admitidas, que, por sua vez, retornam ao campo social, redefinindo*o.

- Todo programa de educação em saúde assenta-se na comunicação entre, pelo menos, dois grupos sociais heterogéneos, população e equipe de saúde, situados em campo sócio-culturais lingüísticos e psicológicos específicos. Ambos buscam a saúde, mas com intençōes, necessidades e concepçōes diferentes. Caso se exclua o sentido que a população atribui as questōes tratadas pelos programas educativos, a comunicação entre ela e a equipe profissional não se operará dentro de um mesmo universo conceitual, gerando conflito entre as orientaçōes técnico-científicas e as ações populares (SPINK, 1992).

- O estudo das representaçöes, portanto, apresenta-se como eixo teórico privilegiado de análise do processo saúde-doença, na medida que possibilita o conhecimento dos referenciais das açōes individuais e coletivas e da maneira como as pessoas se apropriam do conhecimento que circulam na sociedade sobre saúde e doença, remodelando-o.

$O$ ato de representar a realidade transforma o que é estranho em familiar, ancorando o novo em categorias e conteúdos conhecidos. Nesse processo, a memória predomina sobre a lógica e o passado sobre o presente. As representaçōes sociais em conjunçāo com o psíquico colocam questōes básicas à concepção de práticas sanitárias, pois contém a marca da história social e da história pessoal do sujeito.

Nesta perspectiva, estudar representaçōes para trabalhar questōes referentes à saúde é considerar que o corpo, além de ser determinado pelo universalismo das coordenadas biológicas, é antes de mais nada uma realidade simbólica. Por isso mesmo, o indivíduo pode adoecer e até mesmo morrer por impasses inscritos na ordem simbólica. A maioria dos profissionais de saúde que atuam em hospitais sofreram o dilema de enfrentar crenças religiosas que geram determinaçōes inabaláveis de pacientes e familiares na recusa de transfusāo de sangue e de dietas alimentares, mesmo correndo o risco de vida.

O professor de pediatria da Universidade do México e diretor científico do Instituto Nacional de Ciência e Tecnologia para a Saúde da Criança Joaquim Craviotto, ao salientar a falta de informação como a causa principal de desnutrição infantil*, demonstra com clareza a mediação simbólica na relação entre fatores externos e mortalidade infantil. O meio ambiente de carência favorece o aparecimento da doença infantil, mas a relação não é

Ele constatou, através de pesquisa com mảes de igual nivel sócio-económico, que o salto do náo saber ler para saber é táo importante na desnutriçá infantil que os recém-nascidos de máes alfabetizadas tinham 150 gramas a mais na média de peso ao nascer que os bebès de máes analfabetas. 
direta - natural. Segundo ele, ao a nalisar a relaçāo entre condiçōes sócio-económicas e saúde é importante compreender que em situaçōes de extrema pobreza a energia das pessoas são canalizadas 24 horas por dia para evitar a morte. Neste caso nảo há tempo e recurso para investimento de higiene pessoal, habitacional e saneamento básico. Mas é fundamental considerar também, que essa situaçāo é perpetuadora do fatalismo e conservadora de conceitos "ingênuos" de saúde, de enfermidade, como se todas as doenças resultassem de açōes de espíritos. Não é apenas a falta de dinheiro e do acesso aos bens que favorecem as doenças, eles são determinaçōes fundamentais, mas estas determinaçōes são mediadas pelas representaçōes sociais. As pessoas que acreditam que os alimentos recomendados pelos médicos são de fácil contaminaçāo por bactérias e micróbios, como ovos, peixe e carne, para protegerem as crianças nāo lhes dão esses alimentos, mas os chamados carboidratos, criando hábitos alimentares que se perpetuam por geraçōes.

Uma pesquisa financiada pelo Education Office of the Science and Technological Bureau of the United States Agency for International Development (KENDALL et al, 1984), que pode ser definida como abordagem etnomédica de prevenção e desenvolvimento de programas de controle da diarréia em Honduras, demonstrou que os conhecimentos, crenças e práticas loca is de saúde remodelaram os ensinamentos da equipe da saúde. Para conhecer as Representaçōes Sociais que orientam a atividade cotidiana, foram realizadas entrevistas e observaçōes que revelaram doenças folclóricas associadas aos sintomas da diarréia que remetiam a tratamentos específicos, como:

- "empacho": evacuaçōes explosivas causadas por alimentos sujos. Tratamento na base de purgantes.

- "ojo": causada por mal olhado. Tratamento através de benzimentos, recomendando-se umedecer a pele com líquidos.

- "caída de cólera": diarréia causada pela maneira inapropriada da mãe segurar a criança. Tratamento: segurar os pés da criança e sugar a moleira.

Comparando essa pesquisa com outra realizada na Nigéria e no Peru, com a mesma metodologia, (BENTLEY et al, 1981), constata-se que, de um modo geral, as mães forçam a alimentação das crianças com diarréia e nảo se preocupam com a ingestāo de líquidos, demonstrando nảo compreender a relaçāo entre desidrataçāo e diarréia.

- As referidas pesquisas concluíram que os programas educativos, para se tornarem eficientes, precisariam expressar mensagens no vocabulário local, usando o que as mães entendiam por diarréia. Mas apenas expressar mensagem não é suficiente para transformar açōes e relaçōes. Conhecer, sem sentir e agir é mera ideologia; agir, sem conhecer ou sentir é automa- 
tismo; sentir, sem conhecer e agir é apenas fantasia; sentir e pensar sem a possibilidade de ação é loucura/alienação.

Para se promover a saúde não basta ensinar novos conhecimentos e padrōes, é preciso compreender os motivos e emoçōes que medeiam tais conhecimentos e práticas desvelando a base afetiva-volitiva do agir e pensar. Em outras palavras, as relações, a consciència e as açōes nāo são apenas cognitivas ou sociais, elas tem carga afetiva-simbólica.

Representaçāo Social, atividade e afetividade são elementos de um mesmo processo - de orientação da relação com o mundo e com os outros.

Sentir é estar implicado (HELLER, 1974) o que significa avaliar o significado dos objetos e das pessoas, aproximando-se ou afastando-se dos mesmos. Os sentimentos são orientadores da vida cotidiana, eles guiam os contatos humanos. Eles nāo sāo pulsōes naturais e nem funçōes unicamente orgânica e biológicas universais, são representaçōes sociais complexas. Por exemplo, a capacidade da mulher para a maternagem está relacionada às gratificaçōes que retira deste papel, que, por sua vez, estāo relacionadas ao rol de relaçōes afetivas aprendidas socialmente como o amor aos filhos.

Cada momento histórico tem sentimentos dominantes e o mundo burguês dos sentimentos é ideológico, isto é, orientado por valores históricos apresentados como próprios da natureza humana, quando, na verdade, envolvem formas de exploraçāo e dominaçāo.

As emoçōes têm caráter disciplinador. Ela é mobilizada para que o social seja introjetado como operacionalidade cognitiva, como proibição de certos conteúdos (HELLER, 1979). A ideologia autoritária nāo pode ser entendida apenas no plano da racionalidade, ela é marcada pela rigidez com que explica o mundo, e também pela mobilização de sentimentos como vergonha, medo e respeito à autoridade. A vergonha e a culpa quando impostos, heteronomamente, por uma autoridade externa favorecem a subalternidade, fazendo com que o homem aceite a humilhação como natural e se deixe usar como instrumento (HELLER, 1985).

DEJOURS (1988) ao estudar a saúde do subproletário, compreendeu com clareza a relaçāo entre representação, emoção e ação, especialmente entre vergonha e o processo saúde-doença. Ele percebeu que havia uma resistência muito grande em falar da própria doença e sofrimento pelo significado do ato vergonhoso que socialmente é atribuido a este comportamento. Eles faziam associação entre doença e vagabundagem. Estar doente no capitalismo significa interromper o trabalho profissional para os homens e o doméstico para as mulheres, o que equivale a ser irresponsável pelo não cumprimento de seus papéis sociais dominantes.

Enfim, as reflexóes acima pretendem afirmar a importência de estudos sobre a mediação psicossocial do processo saúde-doença para superar a visāo reducionista da relaçāo causal entre organismo biológico e agentes externos, quaisquer que sejam eles, sociais, patogênicos ou psicológicos.

Á luz dessa epistemologia, o corpo humano deixa de ser simples categoria biológica, um fenômeno "hard", para tornar-se o que realmente é, um microcosmo que contém o universal, portanto, bio-psico-sócio-histórico. Saúde 
deixa de ser nāo doença ou estado de pleno bem-estar, para tornar-se possibilidade objetiva e subjetiva de estar sempre buscando este estado, e o direito à saúde se revela como o direito de ter essa possibilidade.

SAWAIA, B. B. Psychosocial analysis of health-illness process. Rev.Esc.Enf.USP, v.28, n.1,p. 105.10, Apr., 1994.

This article is a reflection about the transdiciplinary paradigmas of the healthillness process noting the symbolic mediation between the reactions of the biological , organism and the socio-environment factors including the pathogenic ones. The symbolic-affective mediation is analyzed from the perspective of Social Representation theory allowing one to comprehend the references of individual and collective actions in the health-illness process.

Uniterms: Social representation, symbolic mediation, emotion.

\section{REFERENCIAS BIBLIOGRÁFICAS}

01. BENTLEY, M. E. et al Rapid ethnographic assessment: aplications in a dianhea management program. Soc.BchMed., v.27, n.1, p.107-16, 1988.

02. CONCONE, M.H.V.B. Projeto de Pesquiest estudo epidemiológico das condiçōeo de saúde infantil e prevençáo da desnutriçäo e mortalidade infantil na Regaio de Itapeva, Sảo Paulo, PUC, 1993/mimeografado/.

03. DEJOURS, C. A loucura do trabalho estudo de psicopatologia do trabalho. 3ed.,Sáo Paulo, Cortez, 1988.

04. The power of thame. England, Routledge \& Kegan Paul, 1985.

05. Teorin de low sentimienton. Barcelona. Editorial Fontamara SA, 1979.

06. KENDALL C.et al Ethnomedicine and oral rehydration therapy: a care studies of ethnomedical investigation and program planning. Soc.Sci.Med., v.19, n.3, p. 253-60, 1984.

07. MONTEIRO, P. Da doença de desordem. Rio de Janeiro, Groal, 1985.

08. SPINK, M.J. Psicologin da saúde: a cotruturaçăo de um novo campo do saber. In: CAMPOS, F.C.B.(org.) Paicologita e enúder repensando práticas. São Paulo, Hucitec, 1992. 